\title{
Morphological and Morphometric Study of the Muscle Fibers and Neuromuscular Junctions of the Extensor Digitorum Longus in Aged Rats Submitted to Maternal Protein Restriction
}

\author{
Estudio Morfológico y Morfométrico de las Fibras Musculares y de las \\ Intersecciones Neuromusculares del Músculo Extensor Largo de los Dedos \\ de Ratas de Edad Avanzada Sometidas a la Restricción Proteica Materna
}

Jeronimo, L. C.*; Confortim, H. D.*; Centenaro, L. A.**; Brancalhão, R. M. C.***; Pinheiro, P. F. F. ${ }^{* * * *}$; Matheus, S. M. M.**** \& Torrejais, M. M.**

JERONIMO, L. C.; CONFORTIM, H. D.; CENTENARO, L. A.; BRANCALHÃO, R. M. C.; PINHEIRO, P. F. F.; MATHEUS, S. M. M. \& TORREJAIS, M. M. Morphological and morphometric study of the muscle fibers and neuromuscular junctions of the extensor digitorum longus in aged rats submitted to maternal protein restriction. Int. J. Morphol., 34(1):396-403, 2016.

SUMMARY: Protein restriction implies the functional involvement of several systems and organs, including the skeletal muscle, because it is a protein reservoir in the body. This study sought to analyze the morphological and morphometric features of the muscle fibers and neuromuscular junctions (NMJs) of the extensor digitorum longus (EDL) muscle in rats at 365 days of age, submitted to maternal protein restriction during the gestation and lactation periods. Wistar rats were divided into two groups: a Control Group mothers fed a normal-protein diet (17\% protein) during pregnancy and lactation; and a Restricted Group - mothers fed a low-protein diet ( $6 \%$ protein) during pregnancy and lactation. The pups were kept with the mother throughout the lactation period (21 days), after which the offspring received a normal protein diet until 365 days of age. Histological (HE) and histoenzymological (NADH-TR) studies were conducted on the muscle fibers. The muscle was subjected to Nonspecific Esterase reaction to stain the Neuromuscular Junctions. Regarding the animals from the restricted group: the histologic analysis of the muscle fibers showed the presence of centralized nuclei and a diminished area; the histoenzymological study showed the different types of muscle fibers were randomly distributed in the EDL muscle and the area of the Type IIa muscle fiber was smaller; the ultrastructural study revealed disorganization of the $\mathrm{Z}$ line, and the presence of lipid droplets and vacuoles containing myelin figures in subsarcolemmal and intramiofibrilar regions; while the analysis of the NMJs exhibited no significant differences between the groups. Protein restriction in the pregnancy and lactation period may have affected the development of skeletal muscle, producing a permanent muscle-fiber deficit in the EDL muscle of the offspring.

KEY WORDS: Morphology; Morphometry; Protein restriction; Extensor digitorum longus muscle; Rat.

\section{INTRODUCTION}

Protein-energy malnutrition (PEM) is a multinutritional problem that occurs secondary to deficiency of one or more of the essential nutrients and is characterized by clinical disorders caused by varying degrees of deficiency (Colembergue \& Conde, 2011).

The elderly are affected by non-transmittable chronic diseases that are often closely associated with food intake. A study by Abreu et al. (2008), showed a worrying food situation in the elderly, as almost all the subjects had a low energy intake and a high prevalence of an inadequate intake of protein, vitamins and minerals. Deficiency of one or more essential nutrients is associated with increased mortality and susceptibility to infections, leading to a reduced quality of life in the elderly (Otero et al., 2002; Rezende et al., 2010). The factors found to negatively interfere in energy intake were low income, isolation, medication use and physical inactivity. PEM is mistakenly seen as a normal part of the

\footnotetext{
* Programa de Pós-Graduação em Biociências e Saúde, Universidade Estadual do Oeste do Paraná, Cascavel, Brazil.

** Centro de Ciências Médicas e Farmacêuticas, Universidade Estadual do Oeste do Paraná, Cascavel, Brazil.

*** Centro de Ciências Biológicas e da Saúde, Universidade Estadual do Oeste do Paraná, Cascavel, Brazil.

***** Departamento de Anatomia, Instituto de Biociências, Universidad Estatal Paulista, São Paulo, Brazil.
} 
JERONIMO, L. C.; CONFORTIM, H. D.; CENTENARO, L. A.; BRANCALHÃO, R. M. C.; PINHEIRO, P. F. F.; MATHEUS, S. M. M. \& TORREJAIS, M. M. Morphological and morphometric study of the muscle fibers and neuromuscular junctions of the extensor digitorum long in aged rats submitted to maternal protein restriction. Int. J. Morphol., 34(1):396-403, 2016.

aging process, and often ignored. Deaths from malnutrition in the elderly more often appear as an associated cause than as an underlying cause (Otero et al.).

Malnutrition leads to functional impairment in several systems and organ, including the skeletal muscle (Osmo, 2007). Skeletal muscle tissue is sensitive to protein malnutrition because it is a protein reservoir in the body. Therefore, when there is a deficit of dietary protein, the tissue becomes a target of depletion, causing changes in the growth, function, and differentiation phases of muscle fibers (Brameld, 2004).

With reference to the above, there are few reports in the literature of studies involving aged rodents. Thus, the aim of this study was to evaluate the morphological and morphometric characteristics of the muscle fibers and neuromuscular junctions (NMJs) of the extensor digitorum longus (EDL) muscle of rats at $365 \mathrm{~d}$ of age, submitted to maternal protein restriction during the pregnancy and lactation periods.

\section{MATERIAL AND METHOD}

Animals. Male and female Wistar rats from the animal house of the Department of Anatomy, Institute of Biosciences, UNESP - Botucatu were used and kept under standard lighting conditions $(12 / 12 \mathrm{~h}$ light/dark cycle) and a temperature around $23 \pm 1{ }^{\circ} \mathrm{C}$. This study was approved by the Ethics Committee on Animal Experimentation (CEEA) for "fetal programming by maternal protein restriction in rats", under the protocol certificate No. 264-EAEC.

Mating the Animals. At the beginning of the experiment, two females and one male of reproductive age (12 weeks) were housed in breeding boxes overnight for pairing. In order to verify the presence of sperm, in the morning following pairing the male was removed from the box and the females underwent vaginal smear testing. The presence of sperm in the vaginal smear marked day 0 of pregnancy. Upon detection of pregnancy, the females were moved to individual cages.

On the day of birth, the offspring were weighed and eight pups were kept per mother rat during lactation, to maintain the equal availability of food among all the pups. The pups were kept with the mother during the lactation period $(21 \mathrm{~d})$. After weaning, the male rats received standard solid rodent diet until aged $365 \mathrm{~d}$.

Experimental Groups. Control Group: the offspring of those mothers fed a normal protein diet $(17 \%)$, during the pregnancy and lactation period were fed, following that period, with standard chow (normal protein) for rodents until the age of $365 \mathrm{~d}(\mathrm{n}=5)$.

Restricted Group: the offspring of those mothers fed a low-protein diet $(6 \%)$ during the pregnancy and lactation period were fed, following that period, with standard chow (normal protein) for rodents until the age of $365 d(n=8)$.

Food and water were offered ad libitum for both groups throughout the experiment. The diets were isocaloric and their compositions are shown in Table I.

Animal Euthanasia. The rats were sedated in a $\mathrm{CO}_{2}$ chamber, weighed and subsequently decapitated using a guillotine. The animal was then placed on the operating table to dissect the extensor digitorum longus (EDL). The skin and the anterior tibialis muscle were folded back from the left and right antimeres of the hind limbs, to allow removal of the EDL muscle. Once removed, the muscle was weighed and measured with the aid of a digital caliper (Digimess ${ }^{\circledR}$, São Paulo, Brazil). The right antimere was collected for histological study; the left antimere was sectioned for immunohistochemical study of the end-plates and ultrastructural analysis of the muscle fibers. Soon after, the visceral (VF), retroperitoneal (RF) and epididymal (EF) fats were collected and weighed.

Histologic and Morphometric Study of the Muscle Fibers. For histological analysis of the muscle fibers, muscle fragments from the EDL were removed and fixed in Karnovsky ( $2.5 \%$ sodium phosphate buffer $0.1 \mathrm{M}$ ). After fixation, these fragments were washed in PBS buffer to remove any excess fixative and subsequently embedded in Paraplast. The muscle was embedded in the vertical position to permit later cross-sectioning, with the aid of an embedding center (EasyPath Cygni ${ }^{\circledR}$, São Paulo, Brazil). Five-micronthick sections of the muscle samples were obtained using a microtome (RM2165, Leica ${ }^{\circledR}$, Wetzlar, Germany). The histological sections were mounted on previously silanized slides and submitted to hematoxylin-eosin (HE) staining to reveal the general morphology of the muscle fibers.

For the morphometric analysis of the muscle fibers measurements of the area were taken using the cross-section of the rat EDL muscle prepared for the histological study. The Nuclei and muscle fibers were quantified and the area of each muscle fiber was measured. For each animal from the control and restricted groups, 20 fields were randomly chosen from images captured with a 40x objective, in a light microscope Zeiss - Primo Star, coupled to a AxioCam ERc5s camera, using the AxioVision Rel.4.8 program. The material was analyzed using Image-Pro Plus 6.0 software. 
JERONIMO, L. C.; CONFORTIM, H. D.; CENTENARO, L. A.; BRANCALHÃO, R. M. C.; PINHEIRO, P. F. F.; MATHEUS, S. M. M. \& TORREJAIS, M. M. Morphological and morphometric study of the muscle fibers and neuromuscular junctions of the extensor digitorum longus in aged rats submitted to maternal protein restriction. Int. J. Morphol., 34(1):396-403, 2016.

Table I. Feed composition offered to the animals during pregnancy and lactation.

\begin{tabular}{lcc}
\hline Components* & $\begin{array}{c}\text { Normal protein } \\
(\mathbf{1 7} \% \text { of protein })\end{array}$ & $\begin{array}{c}\text { Low protein } \\
(\mathbf{6} \% \text { of protein })\end{array}$ \\
\hline Casein (84\% protein)** & 202.00 & 71.50 \\
Corn Starch & 397.00 & 480.00 \\
Dextrin & 130.50 & 159.00 \\
Saccharose & 100.00 & 121.00 \\
Soybean Oil & 70.00 & 70.00 \\
Fiber (microcellulose) & 50.00 & 50.00 \\
Mixture of Minerals *** & 35.00 & 35.00 \\
Mixture of Vitamins *** & 10.00 & 10.00 \\
L - cystine & 3.00 & 1.00 \\
Choline Chlorine & 2.50 & 2.50
\end{tabular}

* Diet for gestation stage in rodents - AIN-93G.

** Values corrected according to the protein content of the casein. *** According to AIN-93G.

Histoenzymological Study of the Different Types of Muscle Fibers. For the histoenzymological study of the muscle fibers, the EDL muscle was dissected and kept at room temperature for 30-40 min. After which, the samples were coated with neutral talc to preserve the tissue, frozen in liquid nitrogen for two minutes and stored at $-80{ }^{\circ} \mathrm{C}$ in a Biofreezer. The frozen muscle segments were transferred to the cryostat chamber at $-20^{\circ} \mathrm{C}$ and maintained for 30 $\min$. Then, each segment was attached by one end to a metal support using Tissue Freezing Medium (Leica ${ }^{\circledR}$, Nussloch, Germany). The muscles were sectioned (thickness= seven microns) and the sections obtained were subjected to reaction with Nicotinamide-Adenine Dinucleotide - Tetrazolium Reductase - (NADH-TR), according to the Pearse technique (1972) as modified by Dubowitz \& Brooke (1973).

The microscopic observations and photo documentation were conducted using a Zeiss-Primo Star, light microscope, coupled to an AxioCam ERc5s camera, with the aid of the AxioVision Rel.4.8 program (Zeiss, MicroImaging Inc., Germany).

Measurements of the amount and the cross-sectional area of each muscle fiber type present in the EDL muscle of the rats were conducted, based on the histoenzymological study. For each animal from the control and restricted groups, three fields were randomly selected from images captured with a 20x objective, under a light microscope (Primo Star, Zeiss ${ }^{\circledR}$, Oberkochen, Germany) coupled to a camera (Axiocam ERc5s, Zeiss ${ }^{\circledR}$, Göttingen, Germany), with aid of the AxioVision Rel.4.8 program. The material was analyzed using Image-Pro Plus 6.0 software.

Transmission Electron Microscopy (TEM) Study. For the ultrastructural study, the muscles were removed and reduced to the longitudinal pieces (approximately $1 \mathrm{~mm}$ wide), fixed in Karnovsky's solution and subjected to TEM. In preparation for this, the samples were removed from the fixative and washed in $0.1 \mathrm{M}$ phosphate buffer ( $\mathrm{pH}$ 7.3). Then, the material was immersed in osmium tetroxide for two hours and washed in distilled water. After washing, the samples were immersed in $0.5 \%$ uranyl acetate in water for about $2 \mathrm{~h}$ and subsequently carried dehydrated in an increasing series of acetone $(50 \%, 70 \%, 90 \%$ and $100 \%)$ and finally embedded. After which, the material was sectioned in ultrathin sections (approximately $90 \mathrm{~nm}$ ). The sections were contrasted with saturated uranyl acetate in 50\% alcohol for $20 \mathrm{~min}$ and lead citrate for $10 \mathrm{~min}$.

The material was photographed in a transmission electron microscope (CM100, Philips, Eindhoven, The Netherlands).

Study of the Neuromuscular Junctions (NMJs). A fragment of the EDL muscle was removed and fixed in Karnovsky's solution, kept at room temperature and cut longitudinally in three or four slices with stainless steel blades. The histological sections were subsequently subjected to Nonspecific Esterase reaction (Lehrer \& Ornstein, 1959).

Microscopic observations and photo documentation were conducted under an Olympus BX60 light microscope coupled to an Olympus DP71 camera and, with the aid of the DP Controller 3.2.1 276 program.

Two slides from each animal were used for the morphometric study of the NMJs. In each studied animal, the area and the major and minor diameter of 50 were determined. The images were captured using 20x magnification under a light microscope (Olympus BX-60, Tokyo, Japan), coupled to a camera (Olympus DP71, Tokyo, Japan), with the aid of DP Controller 3.2.1 276 program. The measurements were taken with the aid of Image-Pro Plus 6.0 software. (Media Cybernetics, Maryland, USA).

Statistical Analysis. Data were expressed as Mean \pm Standard Deviation. The results for body weight, muscle weight and length, weight of adipose tissue as well as the area and the major and minor NMJs diameter were compared using Student's t test. The Mann Whitney nonparametric test was used in the case of nonGaussian distribution. 


\section{RESULTS}

Body Weight and VF, RF and EF Weights. Table II shows the data related to body weight and the VF, RF and EF weights which were expressed as mean and standard deviation. The results showed a reduction in body weight and VF, RF and EF weights in animals from the restricted group when compared to those in the control group.

Weight and Length of the EDL Muscle. The EDL muscle weight and length data were expressed as mean and standard deviation (Table II). The results showed there was a reduction in muscle weight in the restricted group when compared with the control group. Regarding the muscle length, in the restricted group the length was shorter than in the control animals.

Morphological Study of the Muscle Fibers. In the control group, the general architecture of the skeletal muscle fibers was preserved; arranged in fascicles surrounded by connective tissue of normal appearance (perimysium). Each fiber had a polygonal or rounded shape, with a peripheral core, surrounded by connective tissue (endomysium) (Fig. 1A). In the restricted group of animals, the appearance of the muscle fibers was similar to that of the control group, although several nuclei were observed in the central position (Fig. 1B).
Table II. Body weight, VF, RF and EF weights, weight and length of the EDL muscle of 365-day-old rats.

\begin{tabular}{lcc}
\hline Parameters & Group Control & Group Restricted \\
\hline Weight Body (g) & $563.0 \pm 26.6$ & $456.9 \pm 21.5^{* * *}$ \\
Weight of VF, RF and EF (g) & $5.262 \pm 2.353$ & $4.540 \pm 1.605^{* *}$ \\
Weight muscle (g) & $0.022 \pm 0.009$ & $0.012 \pm 0.004^{* *}$ \\
Length muscle (mm) & $1.519 \pm 0.679$ & $2.631 \pm 0.930$ \\
\hline
\end{tabular}

Values expressed as Mean \pm Standard Deviation. $* * \mathrm{p}<0.01$ and $* * * \mathrm{p}<0.001$ represent statistical significance.
The results regarding the muscle fiber area, fiber count and number of nuclei for the control and restricted groups are shown in Table III. The analysis of the area showed a significant decrease in the restricted group when compared with the control group.

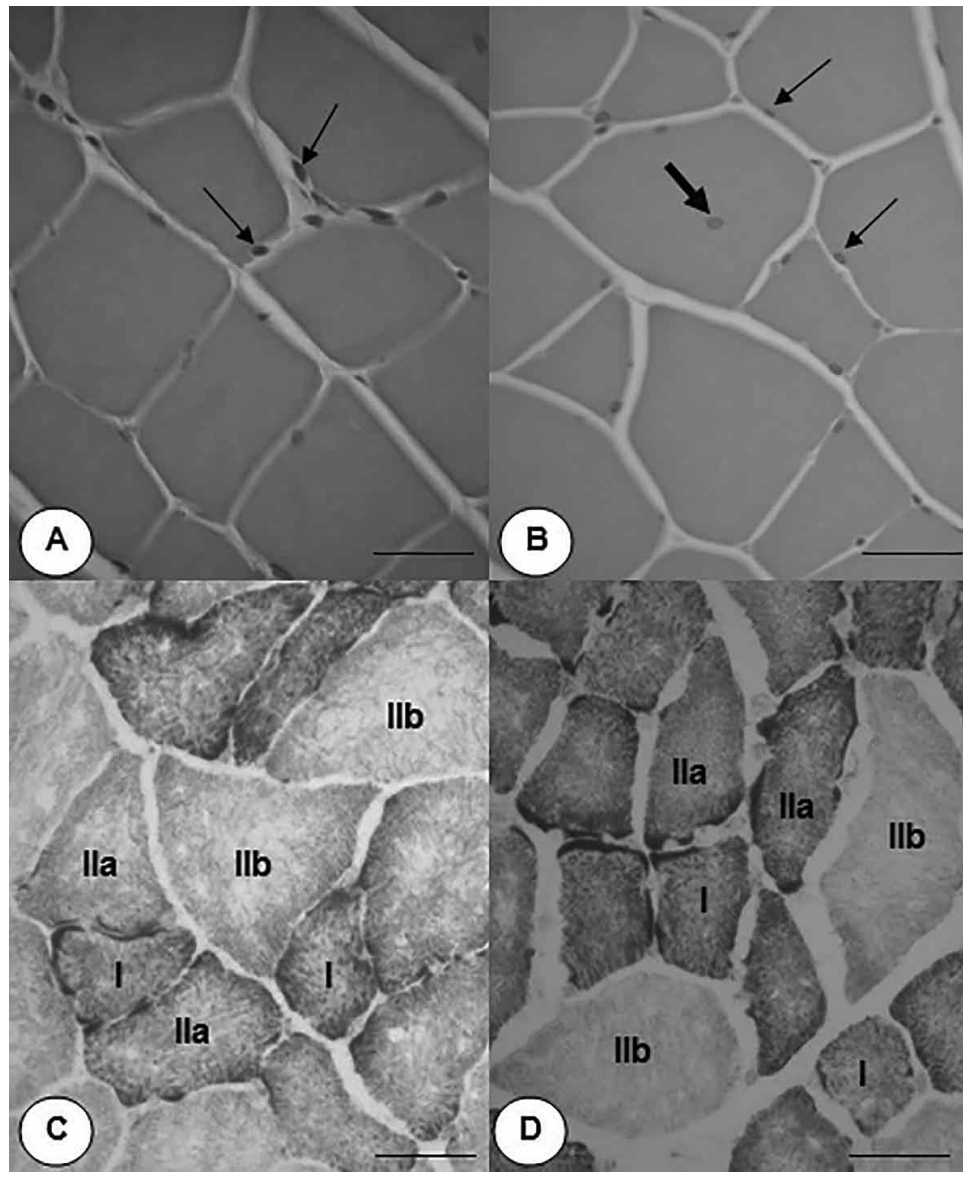

Morphometric and Histoenzymologic Study of the Muscle Fibers. Staining for NADH-TR activity showed the presence of type I muscle fibers (small diameter and intense oxidative activity); type IIa muscle fiber (intermediate diameter and moderate oxidative activity) and type IIb muscle fibers (large diameter and low oxidative activity). These reactions indicate the EDL muscle showed a random distribution of the different types of muscle fibers (Figs. 1C and 1D).

The results for the muscle fiber areas in the control and restricted group animals are shown in Table IV. The area of type IIa muscle fiber was statistically lower in the restricted group compared to the control group. Regarding the fiber count, there was no significant difference between the groups (Table IV).

Fig. 1. Photomicrographs of cross-sections of the EDL muscle of 365-day-old rats stained with $\mathrm{HE}$ (A and B) and NADH-TR (C and D). A: Control group. Normal general architecture; peripheral nuclei (thin arrows). B: Restricted group. Note the presence of centralized nuclei (thick arrow) and peripheral nuclei (thin arrows). Bar= $20 \mu \mathrm{m}$. B and C: Control and restricted groups respectively. Fiber types I, IIa and IIb. Bar $=20 \mu \mathrm{m}$. 

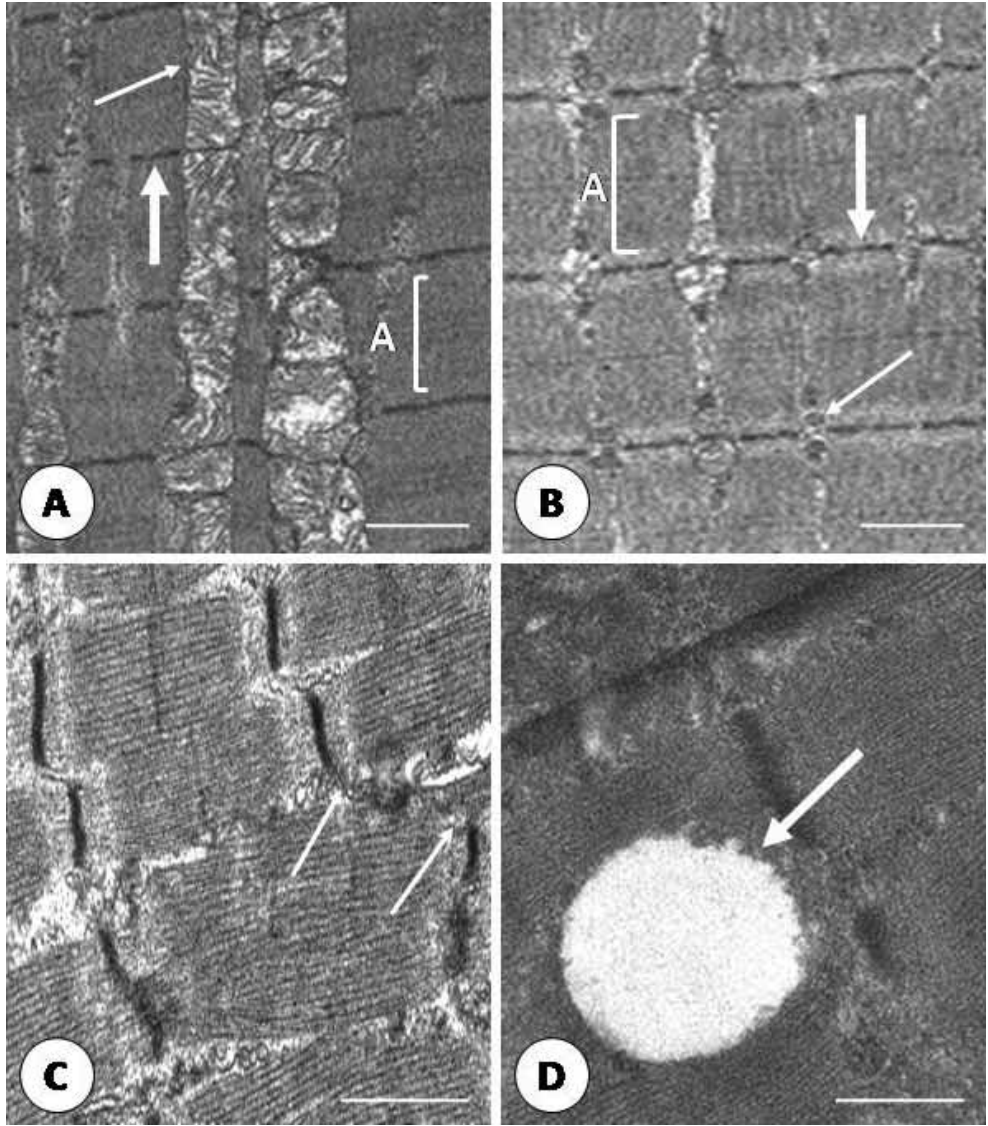

Fig. 2. Transmission Electron micrographs of longitudinal sections of the EDL muscle of 365-day-old rats. A: Control group. Type I fiber, band A (A), Z line (thick arrow) and intermyofibrillary chains of mitochondria (thin arrow). Bar= $2 \mu \mathrm{m}$. B: Control group. Type II Fiber, A band (A) Z-line (thick arrow) and mitochondria in pairs on each side of the $Z$ line (thin arrow). Bar $=2 \mu \mathrm{m}$. C: Restricted group. Note the disorganized $\mathrm{Z}$ line (thin arrows). Bar= $500 \mathrm{~nm}$. D: Restricted group. Lipid droplet (thick arrow). Bar= $500 \mathrm{~nm}$.

Table III. Area, number of muscle fibers and number of nuclei of the EDL muscle of 365-day-old rats.

\begin{tabular}{lcc}
\hline Parameters & Group Control & Group Restricted \\
\hline Fibers muscle area $\left(\mu \mathrm{m}^{2}\right)$ & $2086 \pm 990.8$ & $1912 \pm 1009^{* * *}$ \\
Fibers muscle number & $297.7 \pm 8.5$ & $336.4 \pm 59.6$ \\
Nuclei number & $658.3 \pm 58.2$ & $726.0 \pm 110.2$ \\
\hline
\end{tabular}

Values expressed as Mean \pm Standard Deviation. $* * *$ Represent statistical significance $(\mathrm{p}<0.001)$.
Ultrastructural Study of the Muscle Fibers. In the control animals, two types of muscle fibers were identified. Type I fibers presented a wide and dense $\mathrm{Z}$ line, and evident $\mathrm{M}$ line and $\mathrm{A}, \mathrm{I}$ and $\mathrm{H}$ bands. The mitochondria formed intermyofibrillar chains, in addition to being present in the sarcomeres and subsarcolemmal aggregates. These fibers exhibited oxidative metabolism, are resistant to fatigue and twitch more slowly (Fig. 2A).

Another type of muscle fiber found was the type II, which showed a thin $\mathrm{Z}$ line and evident $\mathrm{M}$ line and $\mathrm{A}, \mathrm{I}$ and $\mathrm{H}$ bands. The mitochondria were always arranged in pairs on each side of the $\mathrm{Z}$ line and I band, were smaller and did not form aggregates or columns. These muscle fibers have a glycolytic metabolism, are poorly resistant to fatigue and are fast twitching (Fig. 2B).

In the animals from the restricted group, the $\mathrm{Z}$ line was disorganized (Fig. 2C) in various regions and in some spots the myofibrils were disorganized. There were notably fewer lipid droplets (Fig. 2D) and myelin figures. Some cell nuclei were seen to be fragmented.

\section{Morphological and Morphometric analysis of the Neuromuscular Junctions. The NMJs present in the EDL muscle from both studied groups showed classical plate-like morphology, being oval, round or elliptical in shape. Variations such as open, irregularly shaped or compact junctions were observed and characterized polymorphisms in these structures seen in several muscles (Figs. 3A and 3B). \\ The results of the analysis of the area and major and minor NMJs diameter are shown in Table V. There was no significant difference between the groups in terms of the area, the major and minor NMJs diameter.}

Table IV. Area and count the muscle fibers in EDL 365-day-old rats.

\begin{tabular}{lcc}
\hline Parameters & Group Control & Group Restricted \\
\hline Area - Muscle Fibers Type I $\left(\mu \mathrm{m}^{2}\right)$ & $1350 \pm 281.7$ & $1301 \pm 243.4$ \\
Area - Muscle Fibers Type IIa $\left(\mu \mathrm{m}^{2}\right)$ & $2302 \pm 406.3$ & $2085 \pm 334.2^{* * *}$ \\
Area - Muscle Fibers Type IIb $\left(\mu \mathrm{m}^{2}\right)$ & $3925 \pm 726.4$ & $3819 \pm 667.7$ \\
Count - Muscle Fibers Type I & $79.2 \pm 16.5$ & $82.0 \pm 18.5$ \\
Count - Muscle Fibers Type IIa & $40.0 \pm 14.4$ & $55.8 \pm 16.7$ \\
Count - Muscle Fibers Type IIb & $73.7 \pm 6.3$ & $65.0 \pm 15.7$ \\
\hline
\end{tabular}

Values expressed as Mean \pm Standard Deviation. ***Represent statistical significance $(\mathrm{p}<0.001)$. 


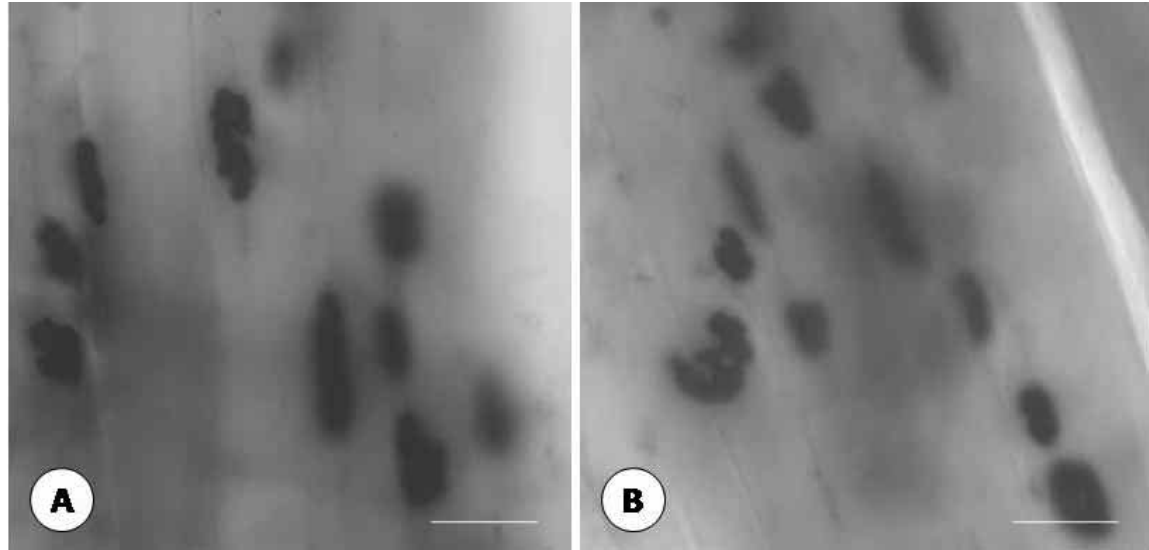

Fig. 3. Photomicrographs of the EDL muscle of 365-day-old rats after reaction for Nonspecific Esterase. A: Control group and B: Restricted group. Note the polymorphism of the NMJs between the studied groups. Bar $=100 \mu \mathrm{m}$.

Table V. Area, major e minor NMJs diameters of the EDL muscle of 365-dayold rats.

\begin{tabular}{lcc}
\hline Parameters & Group Control & Group Restricted \\
\hline Area $\left(\mu \mathrm{m}^{2}\right)$ & $908.7 \pm 413.2$ & $923.5 \pm 681.7$ \\
Major diameter $(\mu \mathrm{m})$ & $49.9 \pm 12.2$ & $49.1 \pm 13.6$ \\
Minor diameter $(\mu \mathrm{m})$ & $20.6 \pm 6.9$ & $20.8 \pm 7.7$ \\
\hline
\end{tabular}

Values expressed as Mean \pm Standard Deviation.

\section{DISCUSSION}

The body weight of the animals from the restricted group was lower than that of the control group. According to Torun \& Chew (1994), decreased body weight is a clinical parameter that characterizes PEM. In the literature, studies using rats (Almeida \& Mello, 2004; Toscano et al., 2008) also found lower weight in the offspring of mothers subjected to protein restriction during pregnancy and/or pregnancy and lactation. However, there are reports that contradict these results, where the animals subjected to protein restriction did not show significant differences in body weight (Oliveira et al., 1999; Cabeço, 2011). These differences may be related to the duration of protein restriction, the type of diet and the age of the animals.

The diet used in this study affected the body weight of the animals even after the change of diet following weaning (normal protein diet - $17 \%$ ) and the deficit remained in the adult animal.

In this experiment, there was a reduction in the weight of the EDL muscle in animals from the restricted group. This finding is in agreement with descriptions in the literature (Toscano et al.) where maternal protein restriction during pregnancy and lactation affected the long-term development of skeletal muscle in the offspring. Bedi et al. (1982) reported that protein energy restriction, when occurring after the lactation period, can be recovered with normalization of the nutritional status, but the changes caused by protein-energy restriction during the period of pregnancy and lactation can cause permanent deficit. Thus, it is believed that the normal protein diet (17\% protein) offered to the offspring in the period following and into adulthood was insufficient to promote the recovery of muscle weight. Rats malnourished during pregnancy and lactation presented reduced weight in the anterior tibialis muscle (Ventrucci et al., 2004; Alves et al., 2008). Although a different muscle, this is a fast twitch muscle similar to that used in this study. The reduction in muscle mass was probably due to the loss of tissue proteins (Alves et al.). By contrast, Cabeço, using the same diet protocol, but with protein restriction only during the gestational stage, found no differences in EDL muscle weight at $30 \mathrm{~d}$ and $16 \mathrm{w}$ of age. This divergence in weight in relation to the present study may be explained by the amount of protein supplied to the offspring during the lactation period and after weaning being sufficient to recover the weight of the EDL muscle.

In the morphological study of the muscle fibers, there was a notable presence of many nuclei in a central position. With migration from the nucleus to the center of the muscle fiber being a common event in muscle disorders. In this study, the presence of centralized nuclei in the restricted animals may be related to the fact the protein restriction period occurred at a critical stage in development of muscle tissue.

The morphometric analysis of muscle fibers in the histological study showed the fiber areas from the animals in the restricted group were significantly smaller than those from the control group. Other studies with rats subjected to protein restriction have also reported a smaller areas in all fiber types (Nascimento et al., 1990; Silvado \& Werneck, 2006; Yan et al., 2012). The literature indicates that protein restriction can compromise the area of type II fibers more than that of type I fibers (Bedi et al.; Chopra et al., 1987; Wilson et al., 1988; Dwyer \& Stickland, 1992; Oliveira et al.; Alves et al.). In this research, the histoenzymological study showed a decreased area in the three types of fibers, 
JERONIMO, L. C.; CONFORTIM, H. D.; CENTENARO, L. A.; BRANCALHÃO, R. M. C.; PINHEIRO, P. F. F.; MATHEUS, S. M. M. \& TORREJAIS, M. M. Morphological and morphometric study of the muscle fibers and neuromuscular junctions of the extensor digitorum longus in aged rats submitted to maternal protein restriction. Int. J. Morphol., 34(1):396-403, 2016.

although it was only significant in the Type IIa fibers. This decrease may be related to the reduction in the animal's body weight and muscle weight, suggesting that protein restriction in the pregnancy and lactation period provokes permanent changes in the area and frequency of muscle fibers (Bedi et al.; Ozanne et al., 2003).

Regarding the number of nuclei and muscle fibers, there were more in the restricted group when compared with the respective control group, but the differences were not significant. The literature contains conflicting results (Bayol et al., 2004), no effect of maternal restriction on the number of fibers in the semitendinosus muscle of rats were found, but there was a reduction in the number of nuclei in the restricted group, indicating a reduction in muscle cell proliferation. Perhaps the increased numbers of nuclei and of fibers found in this study is related to the significant decrease in the area of the fibers.

In the ultrastructure analysis of the muscle fibers in the animals from the restricted group, some changes were observed, such as the disorganization of the $\mathrm{Z}$ line and myofibrils and the presence of few lipid droplets. To the best of our knowledge, in the literature there are no studies dealing with this subject with animals at $365 \mathrm{~d}$ of age, and these alterations in the offspring may well have occurred as a result of the effects of protein restriction during pregnancy and lactation periods.

Regarding the analysis of the area, and the major and minor NMJs diameters, there was no significant alteration in these parameters when the groups were compared. This result was probably due to the polymorphism of the NMJs in the EDL muscle.

The results presented in this paper and their assessment permit the following conclusions: a) The decreased body weight in the restricted animals may be related to maternal protein restriction, which may have affected fetal growth and development, because even with change in diet in the period up to $365 \mathrm{~d}$ of age, the deficit persisted; b) The alterations to the weight of the EDL muscle in animals from the restricted group may have come about because the amount of protein offered to animals in the gestational period and lactation, being sufficient to affect the development of the muscle in the offspring, with longterm consequences since the supply normal protein diet to $365 \mathrm{~d}$ was not sufficient to recover muscle weight; c) The maternal protein restriction may have produced a permanent deficit in the muscle fibers of the offspring, when observed under light microscopy; d) The ultrastructural changes found in the muscle fibers from the restricted animals may be due to maternal protein restriction.

\section{ACKNOWLEDGEMENTS}

The UNIOESTE granted by the infrastructure, the Electronic Microscopy Center of UNESP- Botucatu and technician Gelson Rodrigues of the anatomy department for the great help in all steps of research.

JERONIMO, L. C.; CONFORTIM, H. D.; CENTENARO, L. A.; bRANCAlHÃo, R. M. C.; PINHEIRO, P. F. F.; MATHEUS, S. M. M. \& TORREJAIS, M. M. Estudio morfológico y morfométrico de las fibras musculares y de las intersecciones neuromusculares del músculo extensor largo de los dedos de ratas de edad avanzada sometidas a la restricción proteica materna. Int. J. Morphol., 34(1):396-403, 2016.

RESUMEN: La restricción proteica implica compromiso funcional de diversos sistemas y órganos, entre ellos, el músculo estriado esquelético, por ser una reserva de proteína del organismo. De esa forma, el presente trabajo procuró analizar las características morfológicas y morfométricas de las fibras musculares y de las intersecciones neuromusculares (JNMs) del músculo extensor largo de los dedos (EDL) en ratas de 365 días de edad, sometidas a restricción proteica materna durante los periodos de gestación y lactancia. Las ratas Wistar fueron separadas en dos grupos: El grupo Control - madres alimentadas durante la gestación y lactancia con ración normoproteica ( $17 \%$ de proteína) y Grupo con restricción madres alimentadas durante la gestación y lactancia con ración hipoproteica ( $6 \%$ de proteína). Las crías permanecieron con la madre durante todo el periodo de lactancia (21 días) y después de este periodo la prole recibió ración normoproteica hasta los 365 días de edad. Se realizó un estudio histológico (HE) e histoenzimológico (NADH-TR) de las fibras musculares. Para la marcación de las JNMs, el músculo fue sometido a la reacción de Esterasa Inespecífica. El análisis histológico de las fibras musculares de los animales del Grupo con restricción mostró la presencia de núcleos centralizados y una disminución del área en el grupo con restricción. En el estudio histoenzimológico, el músculo EDL presentó una distribución aleatoria de los diferentes tipos de fibras musculares y el área de las fibras musculares del tipo IIa fue menor en el grupo con restricción. En relación al estudio ultraestructural, en los animales del grupo con restricción se observó desorganización de la línea Z, presencia de pequeñas gotas de lípidos y vacuolas que abrigaban figuras de mielina en las regiones subsarcolemal e intramiofibrilar. En el análisis de las JNMs no hubo diferencias significativas. La restricción proteica impuesta en el periodo de gestación y lactancia puede haber afectado el desarrollo del músculo esquelético, produciendo un déficit permanente en las fibras musculares del músculo EDL de la prole.

PALABRAS ClAVE: Morfología; Morfometría; Restricción proteica; Músculo extensor digitorum longus; Rata. 


\section{REFERENCES}

Abreu, W. C.; Franceschini, S. C. C.; Tinoco, A. L. A.; Pereira, C. A. S. \& Silva, M. M. S. Inadequação no consumo alimentar e fatores interferentes na ingestão energética de idosos matriculados no Programa Municipal da Terceira Idade de Viçosa (MG). Rev. Baiana Saúde Pública, 32(2):190-202, 2008

Almeida, P. B. L. \& Mello, M. A. R. Desnutrição protéica fetal/neonatal, ação da insulina e homeostase glicêmica na vida adulta: efeitos do jejum e do exercício agudo. Rev. Bras. Educ. Fis. Esporte, 18(1):1730, 2004.

Alves, A. P.; Dâmaso, A. R. \& Dal Pai, V. The effects of prenatal and postnatal malnutrition on the morphology, differentiation, and metabolism of skeletal striated muscle tissue in rats. J. Pediatr. (Rio J.), 84(3):264-71, 2008.

Bayol, S.; Jones, D.; Goldspink, G. \& Stickland, N. C. The influence of undernutrition during gestation on skeletal muscle cellularity and on the expression of genes that control muscle growth. Br. J. Nutr., 91(3):331-9, 2004.

Bedi, K. S.; Birzgalis, A. R., Mahon, M.; Smart, J. L. \& Wareham, A. C. Early life undernutrition in rats. 1. Quantitative histology of skeletal muscles from underfed young and refed adult animals. Br. J. Nutr. 47(3):417-31, 1982.

Brameld, J. M. The influence of undernutrition on skeletal muscle development. Br. J. Nutr., 91(3):327-8, 2004.

Cabeço, L. C. Caracterização morfológica, expressão dos fatores de regulação miogênica (MRFS) e dos receptores nicotínicos (NACHRS) no músculo estriado de ratos submetidos à restrição protéica materna. Tese Doutorado em Biologia Geral e Aplicada. Botucatu, Instituto de Biociências, Universidade Estadual Paulista "Júlio de Mesquita Filho"- Botucatu, 2011. pp.95.

Chopra, J. S.; Mehta, J.; Rana, S. V.; Dhand, U. K. \& Mehta, S. Muscle involvement during postnatal protein calorie malnutrition and recovery in rhesus monkeys. Acta Neurol. Scand., 75(4):234-43, 1987.

Colembergue, J. P. \& Conde, S. R. Use of the Mini Nutritional Assessment in institutionalized elderly. Sci. Med. (Porto Alegre), 21(2):59-63, 2011.

Dwyer, C. M. \& Stickland, N. C. Does the anatomical location of a muscle affect the influence of undernutrition on muscle fibre number? $J$. Anat.,181(Pt. 2):373-6, 1992

Dubowitz, V. \& Brooke, M. H. Muscle Biopsy: A Mordern Approach. London, Saunders, 1973.

Lehrer, G. M. \& Ornstein, L. A diazo coupling method for the electron microscopic localization of cholinesterase. J. Biophys. Biochem. Cytol., 6:399-406, 1959.

Nascimento, O. J.; Madi, K.; Guedes e Silva, J. B.; Soares Filho, P. J.; Hahn, M. D.; Couto, B. \& Freitas, M. R. Striated muscle in protein malnutrition: an experimental study in albino rats. Arq. Neuropsiquiatr. 48(4):395-402, 1990.

Oliveira, F. L.; Oliveira, A. S.; Schmidt, B. \& Amancio, O. M. Intrauterine energetic malnutrition in rats: muscle skeletal changes in the 1 st and 2nd generations. J. Pediatr. (Rio J.), 75(5):350-6, 1999.
Osmo, H. G. Alterações metabólicas e nutricionais em pacientes portadores do vírus da imunodeficiência humana e síndrome de imunodeficiência adquirida. Rev. Bras. Nutr. Clin., 22(4):328-35, 2007.

Otero, U. B.; Rozenfeld, S.; Gadelha, A. M. \& Carvalho, M. S. Malnutrition mortality in the elderly, southeast Brazil, 1980-1997. Rev. Saude Publica, 36(2):141-8, 2002

Ozanne, S. E.; Olsen, G. S.; Hansen, L. L.; Tingey, K. J.; Nave, B. T.; Wang, C. L.; Hartil, K.; Petry, C. J.; Buckley, A. J. \& Mosthaf-Seedorf, L. Early growth restriction leads to down regulation of protein kinase $\mathrm{C}$ zeta and insulin resistance in skeletal muscle. J. Endocrinol., 177(2):23541, 2003.

Pearse, A. G. E. Histochemistry: Theoretical and Applied. $3^{\text {rd }}$. ed. Baltimore, Williams \& Wilkins, 1972.

Rezende, E. M.; Sampaio, B. M.; Ishitani, L. H.; Martins, E. F. \& Vilella, L. C. Mortality of malnourished elderly in Belo Horizonte, Minas Gerais State, Brazil: a multidimensional analysis focusing on multiple causes of death. Cad. Saude Publica, 26(6):1109-21, 2010

Silvado, C. E. \& Werneck, L. C. Alterations in the gastrocnemius muscle of undernourished suckling rats. Muscle Nerve, 34(1):72-7, 2006.

Torun, B. \& Chew, F. Protein-Energy Malnutrition. In: Shils, M. E.; Olson, J. A.; Shike, M. \& Ross, A. C. (Eds.). Modern Nutrition in Health and Disease. Philadelphia, Lea \& Febiger, 1994. pp.950-76.

Toscano, A. E.; Manhães-de-Castro, R. \& Canon, F. Effect of a low-protein diet during pregnancy on skeletal muscle mechanical properties of offspring rats. Nutrition, 24(3):270-8, 2008 .

Ventrucci, G.; Ramos Silva, L. G.; Roston Mello, M. A. \& Gomes Marcondes, M. C. Effects of a leucine-rich diet on body composition during nutritional recovery in rats. Nutrition, 20(2):213-7, 2004.

Wilson, S. J.; Ross, J. J. \& Harris, A. J. A critical period for formation of secondary myotubes defined by prenatal undernourishment in rats. Development, 102(4):815-21, 1988.

Yan, X.; Zhu, M. J.; Dodson, M. V. \& Du, M. Developmental programming of fetal skeletal muscle and adipose tissue development. J. Genomics, 1:29-38, 2013.

Correspondence to:

Prof ${ }^{a}$. Dra . Marcia Miranda Torrejais

Centro de Ciências Médicas e Farmacêuticas

Universidade Estadual do Oeste do Paraná

UNIOESTE - 85814-110

Cascavel, Paraná

BRAZIL

Email: mmtorrejais@yahoo.com.br

Received: 19-05-2015

Accepted: 09-12-2015 